\title{
Sistem Informasi Layanan Surat Internal Dan Eksternal Berbasis Web
}

\author{
Muhammad Ilham¹, Susan Dian Purnamasari2 \\ Informatics Departement, Bina Darma University, Palembang, Indonesia \\ Information System Departement, Bina Darma University, Palembang, Indonesia \\ Email: 1ilhampalembang1998@gmail.com, 2susandian@binadarma.ac.id
}

\begin{abstract}
Abstrak
Penelitian ini bertujuan untuk mengetahui sistem informasi layanan surat internal dan eksternal serta hambatan-hambatannya yang di dirancang menggunakan web dengan bahasa pemrograman php. Namun dalam hal ini pelaksanaan Sistem informasi surat menyurat di pemerintah kabupaten empat lawang masih mengalami beberapa kendala, seperti dalam hal layanan surat masuk maupun surat keluar. Oleh sebab itu, maka dikembangkanlah sistem informasi surat menyurat tersebut dengan tujuan untuk membantu proses layanan surat internal dan eksternal sehingga dapat mempercepat pekerjaan. Dalam penelitian ini metode pengembangan menggunakan metode prototipe, serta alat bantu yang digunakan adalah UML (Unified Model Language). Sedangkan pembuatan aplikasinya sendiri menggunakan bahasa pemrograman Hypertext Preprocessor (PHP) dengan MySQL untuk pengolahan databasenya, Perancangan sistem ini memiliki komponen seperti klasifikasi surat, data surat masuk, data surat keluar dan agenda sistem pengarsipan, sistem ini membuat solusi lebih cepat dalam proses persuratan dan pengarsipan yang dilakukan secara konvensional.
\end{abstract}

Kata kunci : Sistem Informasi surat menyurat, Prototype, Unified Model Language (UML), PHP, MYSQL.

\section{PENDAHULUAN}

Pengelolaan surat masuk dan surat keluar pada Pemerintahan Kabupaten Empat Lawang melibatkan banyak jurnal atau kertas yang harus diisi untuk mencatat dan mengelompokkan surat masuk maupun surat keluar. Contohnya ketika ada surat masuk, maka petugas akan mengisi buku daftar pengendali surat masuk dan lembar disposisi surat sesuai dengan data surat masuk yang ada [1].

Saat ini terdapat permasalahan yang terjadi Pemerintahan Kabupaten Empat Lawang dalam layanan surat menyurat, ketidaktersediaan Sistem yang dapat digunakan untuk mengolah data-data pengelolaan surat masuk dan surat keluar 
serta data yang ada saat ini masih menggunakan pencatatan pada Microsoft Office Excel yang mengakibatkan keterlambatan dalam memproses data. Sehingga membutuhkan waktu yang lama dan proses yang panjang dan menyulitkan dalam pengolahan data, pencarian data, dan pembuatan laporan. [2]

Dalam penelitian ini metode pengembangan menggunakan metode prototipe, serta alat bantu yang digunakan adalah UML (Unified Model Language). Sedangkan pembuatan aplikasinya sendiri menggunakan bahasa pemrograman Hypertext Preprocessor (PHP) dengan MySQL untuk pengolahan databasenya, Perancangan sistem ini memiliki komponen seperti klasifikasi surat, data surat masuk, data surat keluar dan agenda sistem pengarsipan, sistem ini membuat solusi lebih cepat dalam proses persuratan dan pengarsipan yang dilakukan secara konvensional. [3]

\section{METODOLOGI PENELITIAN}

\subsection{Metode Pengembangan Prototype}

Model Prototype merupakan salah satu model dalam SDLC yang mempunyai ciri khas sebagai model proses evolusioner. Prototype Model dimulai dari mengumpulkan kebutuhan pengguna terhadap perangkat lunak yang akan dibuat. Adapun gambar tahapan metode prototype dapat dilihat pada gambar 1 .

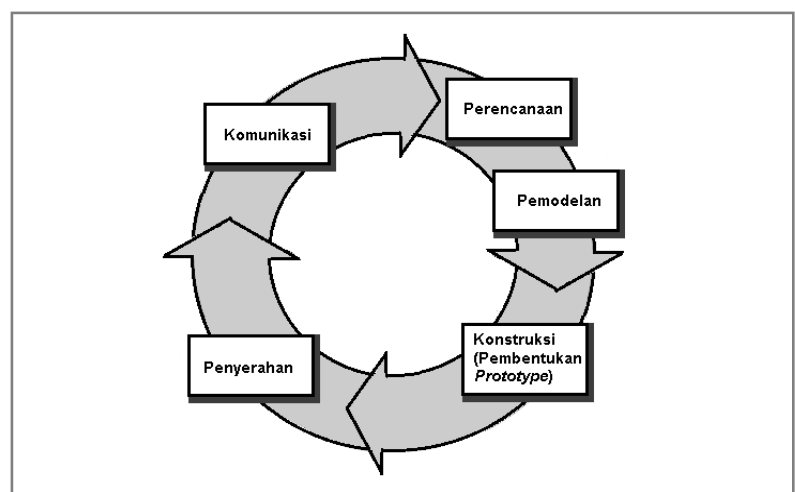

Gambar 1 Tahapan Metode Prototype[4]

1) Komunikasi, Tahapan ini mengidentifikasi permasalahan-permasalahan yang ada, serta informasi-informasi lain yang diperlukan untuk pengembangan sistem. Perencanaan,

2) Perencanaan, Tahapan ini dikerjakan dengan kegiatan penentuan sumberdaya, spesifikasi untuk pengembangan berdasarkan kebutuhan 
sistem, dan tujuan berdasarkan pada hasil komunikasi yang dilakukan agar pengembangan dapat sesuai dengan yang diharapkan

3) Pemodelan, Tahapan selanjutnya ialah representasi atau menggambarkan model sistem yang akan dikembangkan seperti proses dengan perancangan menggunakan Use Case (Class Diagram) relasi antar-entitas yang diperlukan, dan perancangan antarmuka dari sistem yang akan dikembangkan.

4) Konstruksi, Tahapan ini digunakan untuk membangun, menguji-coba sistem yang dikembangkan. Proses instalasi dan penyediaan usersupport juga dilakukan agar sistem dapat berjalan dengan sesuai.

5) Penyerahan, Tahapan ini dibutuhkan untuk mendapatkan feedback dari pengguna, sebagai hasil evaluasi dari tahapan sebelumnya dan implementasi dari sistem yang dikembangkan [5].

\section{HASIL DAN PEMBAHASAN}

3.1 Proses Aplikasi Surat Keluar Adapun aplikasi surat keluar pada aplikasi ini dapat dilihat pada gambar 2

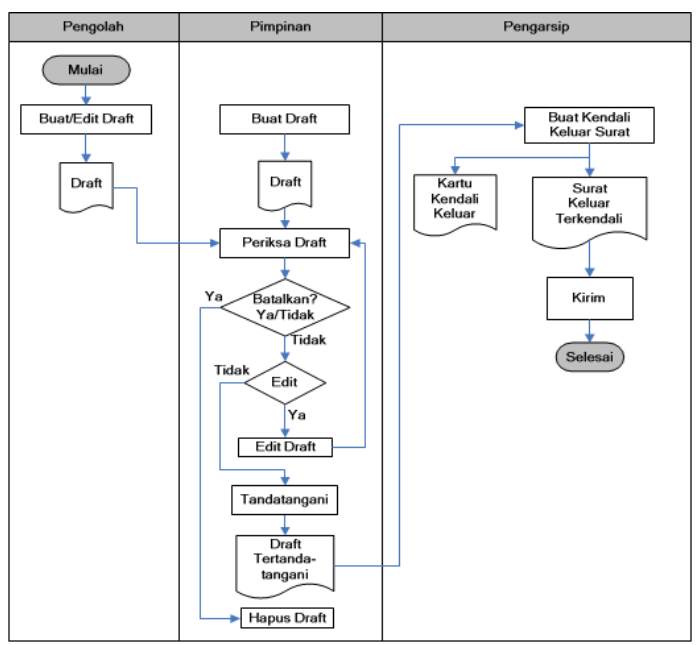

Gambar 2 Diagram Prosedur Proses Aplikasi Surat Keluar

\subsection{Proses Aplikasi Surat Masuk}

Proses surat masuk elektronik dimulai ketika Pengarsip menerima surat masuk. Apabila surat masuk berupa dokumen fisik maka surat harus dipindai dahulu menjadi dokumen digital kemudian diupload kedalam sistem dan apabila surat 


\section{Journal of Information Technology Ampera}

Vol. 2, No. 3, December 2021 e-ISSN: 2774-2121

https://journal-computing.org/index.php/journal-ita/index

masuk berupa dokumen elektronik maka surat dapat langsung dibuatkan kendali masuk. Selanjutnya surat masuk akan disampaikan kepada Pimpinan untuk diterima dan dibaca.

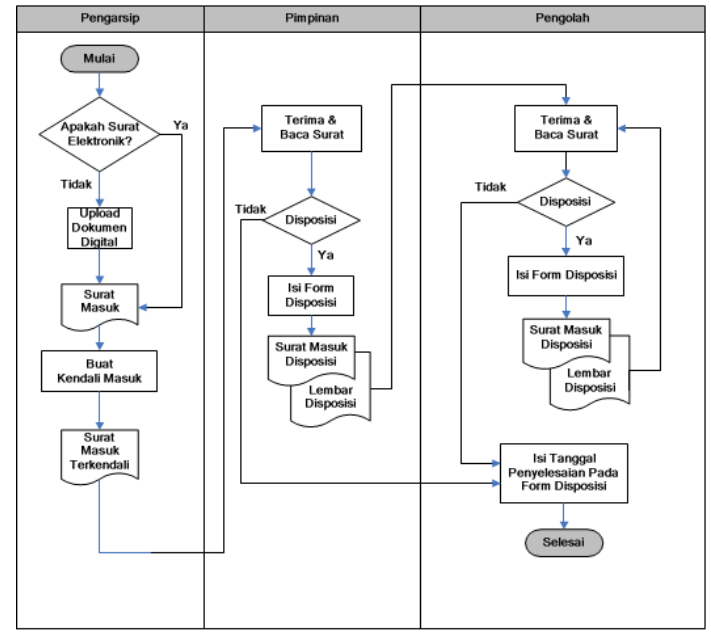

Gambar 3 Diagram Prosedur Proses Aplikasi Surat Masuk

\subsection{Analisis Kebutuhan Sistem}

Tabel 1. Analisis Kebutuhan Sistem

\begin{tabular}{|c|c|c|c|c|}
\hline No. & Proses & Masukan & Keluaran & Antarmuka \\
\hline 1. & Login & $\begin{array}{c}\text { Username dan } \\
\text { password }\end{array}$ & $\begin{array}{c}\text { Informasi } \\
\text { Login }\end{array}$ & $\begin{array}{c}\text { Halaman } \\
\text { Login }\end{array}$ \\
\hline 2. & $\begin{array}{l}\text { Manajemen Surat Masuk } \\
\text { (melihat, menambah, } \\
\text { mengubah, menghapus } \\
\text { dan mencetak laporan) }\end{array}$ & $\begin{array}{l}\text { Kode surat, } \\
\text { nomor surat, } \\
\text { tanggal surat, asal } \\
\text { surat, index surat, } \\
\text { isi surat, } \\
\text { gambar surat dan } \\
\text { jumlah lampiran } \\
\text { surat }\end{array}$ & \begin{tabular}{|l|} 
Informasi \\
surat masuk \\
dan laporan \\
surat masuk \\
dalam bentuk \\
Excel
\end{tabular} & \begin{tabular}{|l|} 
Halaman \\
surat masuk, \\
halaman \\
tambah data \\
surat masuk, \\
halaman ubah \\
data surat \\
msuk
\end{tabular} \\
\hline
\end{tabular}




\begin{tabular}{|c|c|c|c|c|}
\hline & $\begin{array}{l}\text { Manajemen Disposisi } \\
\text { Surat (melihat, } \\
\text { menambah, mengubah, } \\
\text { menghapus dan cetak } \\
\text { halaman disposisi surat)' }\end{array}$ & $\begin{array}{l}\text { Tanggal } \\
\text { penyelesaian } \\
\text { disposisi surat, } \\
\text { tujuan disposisi } \\
\text { dan instruksi } \\
\text { disposisi }\end{array}$ & $\begin{array}{l}\text { Informasi } \\
\text { disposisi } \\
\text { surat dan } \\
\text { halaman } \\
\text { disposisi } \\
\text { surat dalam } \\
\text { bentuk PDF }\end{array}$ & \begin{tabular}{|l|} 
Halaman \\
disposisi \\
surat, \\
halaman \\
tambah data \\
disposisi, \\
halaman ubah \\
data disposisi \\
dan halaman \\
hapus \\
disposisi
\end{tabular} \\
\hline 4. & $\begin{array}{l}\text { Manajemen Surat Keluar } \\
\text { (melihat,menambah,men } \\
\text { gubah, menghapus dan } \\
\text { mencetak laporan) }\end{array}$ & $\begin{array}{l}\text { Kode surat, } \\
\text { pengolah surat, } \\
\text { nomor surat, } \\
\text { tujuan surat, } \\
\text { tanggal surat, } \\
\text { index surat, } \\
\text { catatan, file } \\
\text { gambar isi surat, } \\
\text { jumlah lampiran } \\
\text { surat dan jumlah } \\
\text { lembar surat }\end{array}$ & $\begin{array}{l}\text { Informasi } \\
\text { surat keluar } \\
\text { dan laporan } \\
\text { surat keluar } \\
\text { dalam bentuk } \\
\text { Excel }\end{array}$ & \begin{tabular}{|l|} 
Halaman \\
surat keluar, \\
halaman \\
tambah data \\
surat keluar, \\
halaman ubah \\
data surat \\
keluar dan \\
halaman \\
hapus data \\
surat keluar
\end{tabular} \\
\hline 5. & $\begin{array}{l}\text { Manajemen Kode Surat } \\
\text { (melihat, menambah, } \\
\text { mengubah dan } \\
\text { menghapus) }\end{array}$ & $\begin{array}{l}\text { Kode surat, nama } \\
\text { kode surat dan } \\
\text { keterangan kode }\end{array}$ & $\begin{array}{l}\text { Informasi } \\
\text { kode surat }\end{array}$ & \begin{tabular}{|l|} 
Halaman \\
kode surat, \\
halaman ubah \\
data kode \\
surat, \\
halaman ubah \\
data kode \\
surat dan \\
halaman \\
hapus \\
kode surat
\end{tabular} \\
\hline
\end{tabular}




\begin{tabular}{|c|c|c|c|c|}
\hline 6. & $\begin{array}{l}\text { Manajemen Agenda } \\
\text { Acara (melihat, } \\
\text { menambah, mengubah } \\
\text { dan menghapus) }\end{array}$ & \begin{tabular}{|l|} 
Tanggal acara, \\
tempat \\
pelaksanaan, \\
waktu \\
pelaksanaan, \\
peserta dan detail \\
acara
\end{tabular} & lnformasi & \begin{tabular}{|l|} 
Halaman \\
agenda acara, \\
halaman \\
tambah data \\
agenda acara, \\
halaman ubah \\
data agenda \\
acara dan \\
halaman \\
hapus data \\
agenda acara
\end{tabular} \\
\hline 7. & $\begin{array}{l}\text { Manajemen Data } \\
\text { Pegawai (melihat, } \\
\text { menambah, mengubah } \\
\text { dan menghapus) }\end{array}$ & $\begin{array}{l}\text { NIP, nama } \\
\text { lengkap, jenis } \\
\text { kelamin, tempat } \\
\text { lahir, tanggal lahir, } \\
\text { kontak dan } \\
\text { alamat }\end{array}$ & $\begin{array}{l}\text { Informasi } \\
\text { data pegawai }\end{array}$ & \begin{tabular}{|l|} 
Halaman \\
pegawai, \\
halaman \\
tambah data \\
pegawai, \\
halaman ubah \\
data pegawai \\
dan halaman \\
hapus data \\
Pegawai
\end{tabular} \\
\hline 8. & $\begin{array}{l}\text { Manajemen Data Jabatan } \\
\text { (melihat, } \\
\text { menambah,mengubah } \\
\text { dan menghapus) }\end{array}$ & $\begin{array}{l}\text { Nama jabatan } \\
\text { dan tujuan } \\
\text { disposisi }\end{array}$ & $\begin{array}{l}\text { Informasi } \\
\text { data jabatan }\end{array}$ & \begin{tabular}{|l|} 
Halaman \\
jabatan, \\
halaman \\
tambah \\
data jabatan, \\
halaman ubah \\
\end{tabular} \\
\hline
\end{tabular}

\subsection{Membangun Prototyping}

\subsubsection{Perancangan Sistem}

Perancangan sistem adalah untuk membuat sistem informasi surat internal dan eksternal berbasis web ini yang dapat membantu pegawai untuk mengelola surat masuk dan surat keluar di Pemerintahan Kabupaten Empat Lawang, Perancangan sistem meliputi usecase diagram, activity diagram, 
1). Use Case Diagram

Use Case diagram menggambarkan fungsionalitas yang diharapkan dari sebuah aplikasi yang hendak dikembangkan.

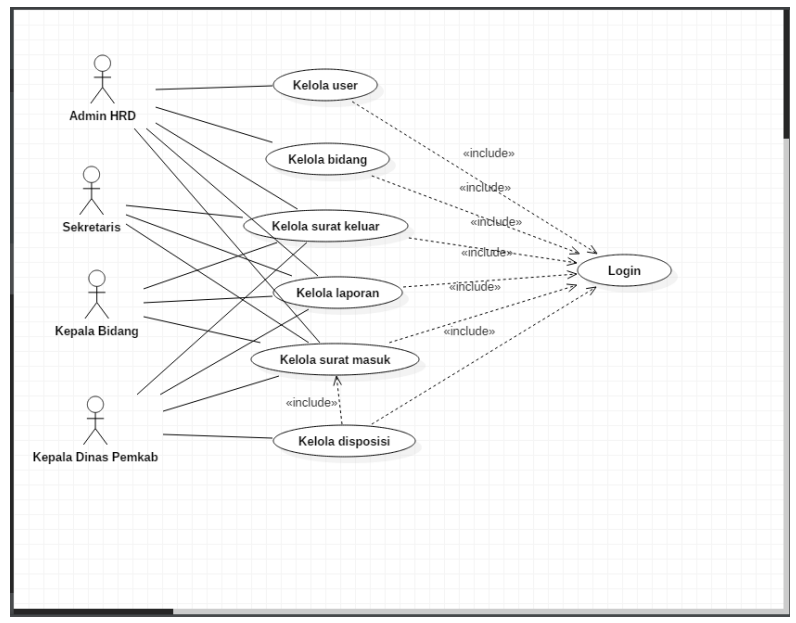

Gambar 4 Use Case Diagram Aplikasi layanan surat internal dan eksternal

Pada Use Case Diagram diatas, dapat dilihat bahwa Admin dapat mengakses seluruh activity yang ada dalam aplikasi, baik itu memasukkan data ataupun melihat serta mengunduh surat masuk dan surat keluar, tetapi user untuk hanya sebatas mengakses aplikasi tersebut dan tidak bisa menambahkan dan menghapus data user.

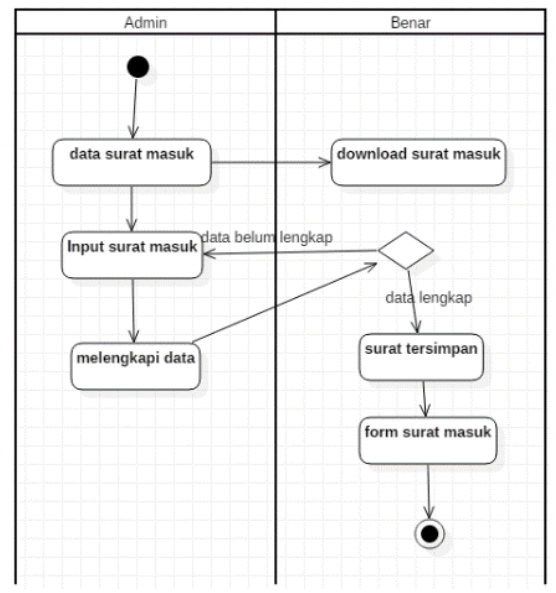

Gambar 5 Activity Dagram Form Surat Masuk 


\section{Journal of Information Technology Ampera}

Vol. 2, No. 3, December 2021 e-ISSN: 2774-2121

https://journal-computing.org/index.php/journal-ita/index

Pada Form surat masuk dapat dilihat bahwa admin dapat menginput surat masuk dan dapat mendownload surat masuk yang sudah ada jika di perlukan.

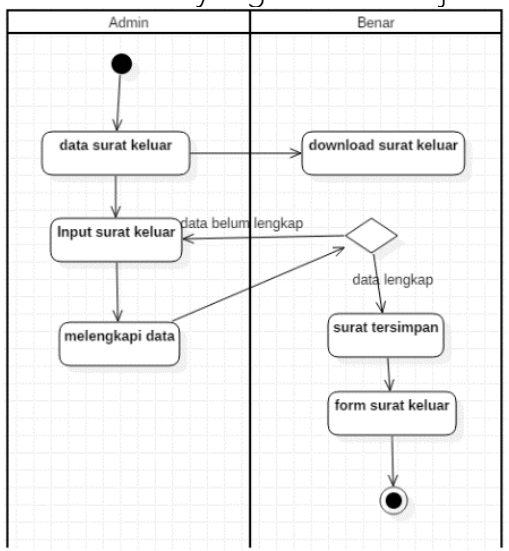

Gambar 6 Activity Diagram Form Surat Keluar

Pada Form surat keluar dapat dilihat bahwa admin dapat menginput surat keluar dan dapat men-download surat masuk yang sudah ada jika di perlukan.

\subsection{Rancangan Interface}

Prinsip dari perancangan antarmuka yang baik adalah user friendly, yang memudahkan pengguna dalam menggunakan aplikasi yang akan dibangun.

\subsubsection{Rancangan Halaman Login}

Adapun Halaman utama pada layanan surat menyurat Pemerintahan Kabupaten empat lawang yang tertara pada gambar 7

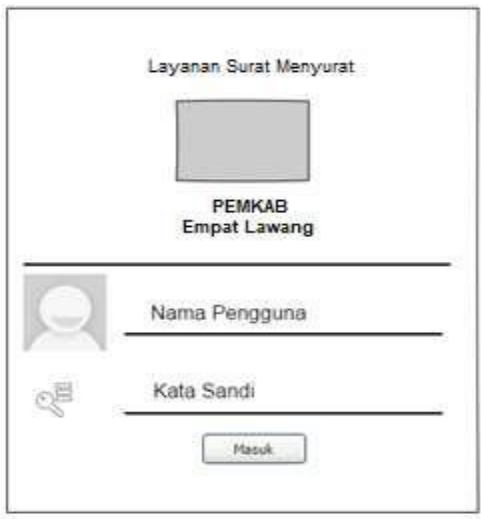

Gambar 7 Halaman Login 
Pada rancangan halaman login pengelolaan surat ada beberapa fitur yang diantaranya pengguna harus masuk terlebih dahulu dengan mengisi nama pengguna dan kode pengguna

\subsubsection{Rancangan Halaman Utama Pengguna}

Adapun rancangan utama halaman pengguna dapat dilihat pada gambar 8 sebagai berikut :

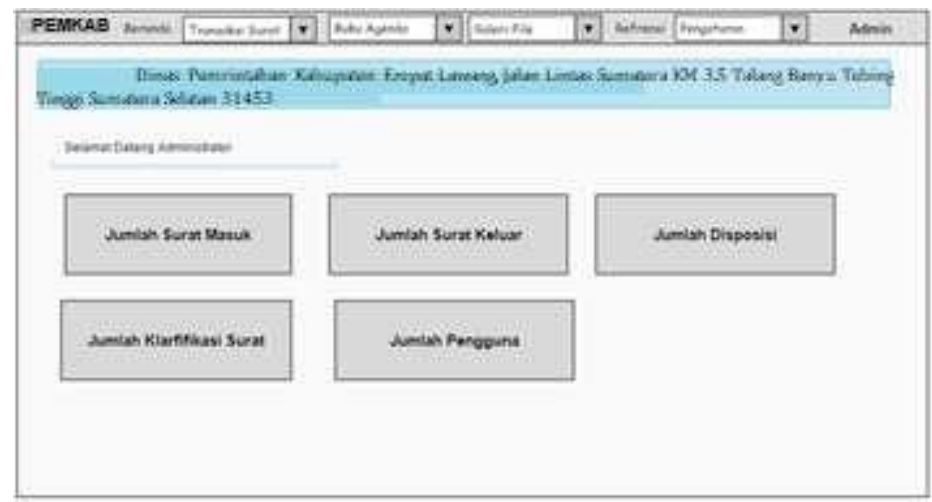

Gambar 8 Halaman Utama

\subsubsection{Rancangan Surat masuk Pengguna}

Adapun rancangan surat pengguna masuk dapat dilihat pada gambar 9 sebagai berikut

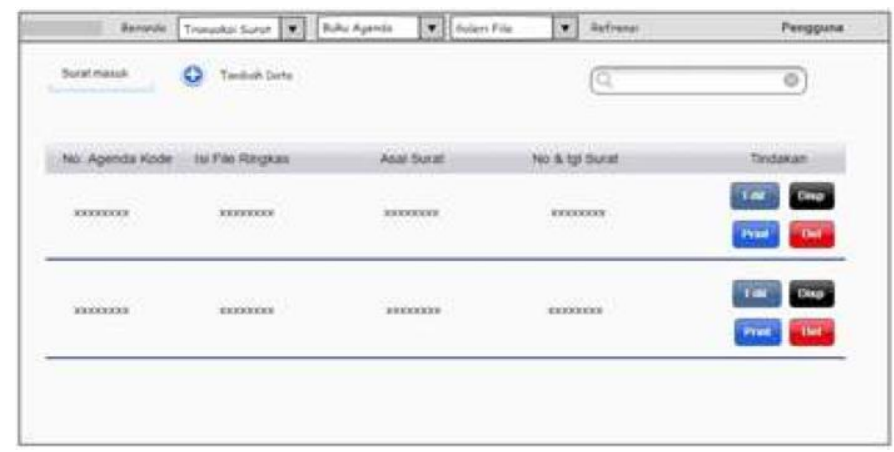

Gambar 9 Halaman rancangan surat masuk pengguna

Pada rancangan surat masuk berisikan nomor agenda, isi file, asal surat, nomor dan tanggal surat serta tindakan atau opsi yang dimana pengguna bisa mengubah, mendisposisi, print surat masuk serta menghapus surat masuk. 


\section{Journal of Information Technology Ampera}

Vol. 2, No. 3, December 2021 e-ISSN: 2774-2121

https://journal-computing.org/index.php/journal-ita/index

\subsubsection{Rancangan Surat keluar Pengguna}

Adapun rancangan surat keluar Pengguna masuk dapat dilihat pada gambar 10 sebagai berikut :

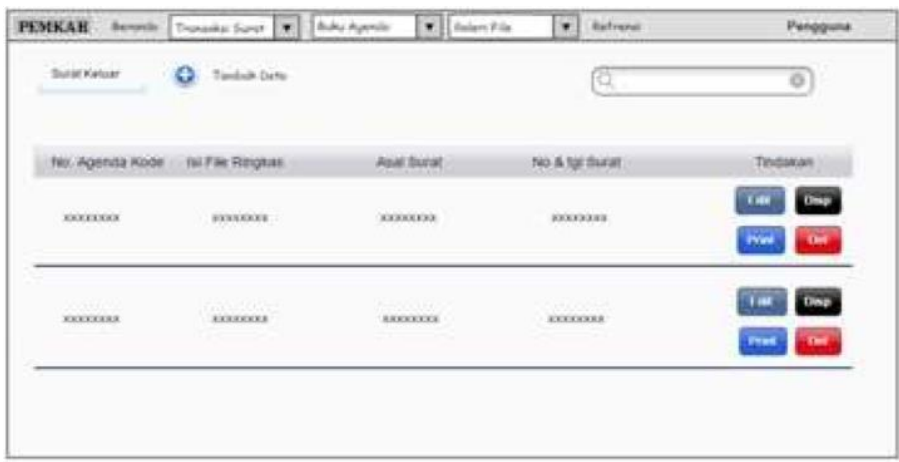

Gambar 10 Halaman rancangan surat keluar pengguna

Pada rancangan surat keluar berisikan nomor agenda, isi file, asal surat, nomor dan tanggal surat serta tindakan atau opsi yang dimana pengguna bisa mengubah, mendisposisi, print surat masuk serta menghapus surat masuk.

\subsection{Executable Software}

Implementasi adalah suatu proses penerapan rancangan program yang telah dibuat sesuai dengan analisis yang telah dirancang sebelumnya, sehingga dapat menjadi sebuah aplikasi.

1) Tampilan Dashboard

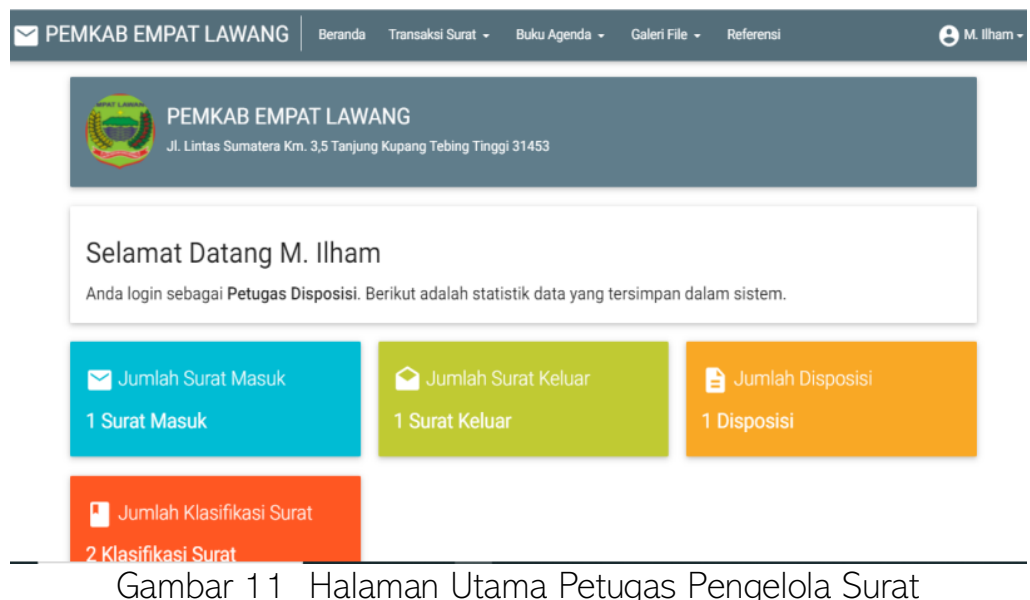




\section{Journal of Information Technology Ampera}

Vol. 2, No. 3, December 2021 e-ISSN: 2774-2121

https://journal-computing.org/index.php/journal-ita/index

2) Tampilan Manajemen Surat Masuk

Pada menu ini pengguna akan ditampilkan tabel berisi data surat masuk yang sudah dimasukkan ke dalam sistem. Tampilan dalam melihat data surat masuk dapat dilihat pada Gambar 12

च PEMKAB EMPAT LAWANG $\mid$ Beranda Transaksi Surat - Buku Agenda - Galer File - Referensi

\section{च Surat Masuk $\odot$ Tambah Data}

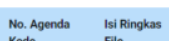

File

vaksinasi covid

File : 4467-Alham1.PNG
Q Ketik dan tekan enter mencari data.

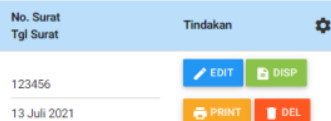

Gambar 12 Halaman Manajemen Surat Masuk

3) Tampilan Surat Masuk

Tampilan dalam melihat data surat masuk dapat dilihat pada Gambar 13

\begin{tabular}{|c|c|c|}
\hline 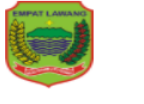 & \multicolumn{2}{|c|}{$\begin{array}{l}\text { DINAS PEMERINTAHAN KABUPATEN EMPAT LAWANG } \\
\text { PEMKAB EMPAT LAWANG } \\
\text { DINAS PEMERINTAHAN } \\
\text { J. Lintas Sumatera Km. } 3,5 \text { Tanjung Kupang Tebing Tinggi } 31453\end{array}$} \\
\hline \multicolumn{3}{|c|}{ LEMBAR DISPOSISI } \\
\hline Indeks Berkas & : ndkasnkas & Kode: 2 \\
\hline Tanggal Surat & : 13 Juli 2021 & \\
\hline Nomor Surat & $: 123456$ & \\
\hline Asal Surat & :Palembang & \\
\hline Isi Ringkas & : vaksinasi covid & \\
\hline Diterima Tanggal & : 12 Juli 2021 & No. Agenda : 2 \\
\hline Tanggal Penyelesaian & & \\
\hline 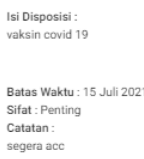 & & $\begin{array}{l}\text { Diteruskan Kepada } \\
\text { Vaksinasi }\end{array}$ \\
\hline
\end{tabular}

Kepala Permkab Empattawang

Gambar 13 Halaman Gambar Surat Masuk

4) Tampilan Cetak Disposisi Surat

Tampilan saat halaman cetak disposisi pada Gambar 14 


\section{Journal of Information Technology Ampera}

Vol. 2, No. 3, December 2021 e-ISSN: 2774-2121

https://journal-computing.org/index.php/journal-ita/index

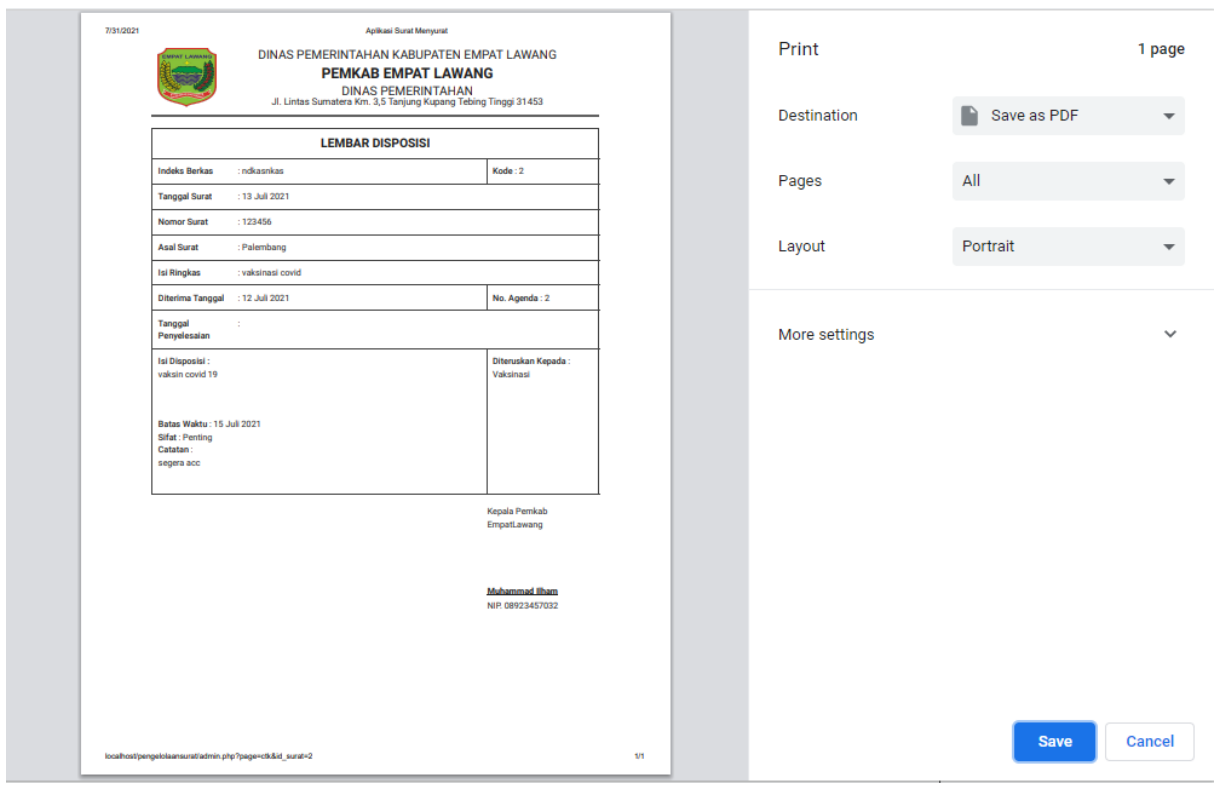

Gambar 14 Halaman Cetak Disposisi Surat

5) Manajemen Surat Keluar

Pada menu ini pengguna akan ditampilkan tabel berisi data surat keluar yang sudah dimasukkan ke dalam sistem. Tampilan dalam melihat data surat keluar dapat dilihat pada Gambar 15

\begin{tabular}{|c|c|c|c|c|c|}
\hline$\Leftrightarrow$ Sur & $\odot$ Tambah Data & & etik dan teka & lata.. & \\
\hline $\begin{array}{l}\text { No. Agenda } \\
\text { Kode }\end{array}$ & $\begin{array}{l}\text { Isi Ringkas } \\
\text { File }\end{array}$ & Tujuan & $\begin{array}{l}\text { No. Surat } \\
\text { Tgl Surat }\end{array}$ & Tindakan & \\
\hline 2 & Pelaksanaan Try Out & \multirow{2}{*}{ Dinas Pendidikan } & S002 & \multirow[t]{2}{*}{ EDIT } & \multirow[t]{2}{*}{ DEL } \\
\hline 01 & File: 340 -illham2.png & & 31 Juli 2021 & & \\
\hline 1 & Vaksinasi Tahap 2 Covid 19 & \multirow{2}{*}{ Dinas Pendidikan Empat Lawang } & S001 & \multirow{2}{*}{\multicolumn{2}{|c|}{ ONOACTION }} \\
\hline 01 & File : 2895-Lambang_Empat_Lawang.png & & 28 Juli 2021 & & \\
\hline
\end{tabular}

Gambar 15 Halaman Manjemen Surat Keluar

Di dalam tabel pada Gambar 15 pada terdapat tombol berwarna biru untuk dapat melihat gambar surat keluar yang sudah dimasukkan oleh pengguna. Tampilan dalam melihat data surat keluar dapat dilihat pada Gambar 16 


\section{Journal of Information Technology Ampera}

Vol. 2, No. 3, December 2021 e-ISSN: 2774-2121

https://journal-computing.org/index.php/journal-ita/index

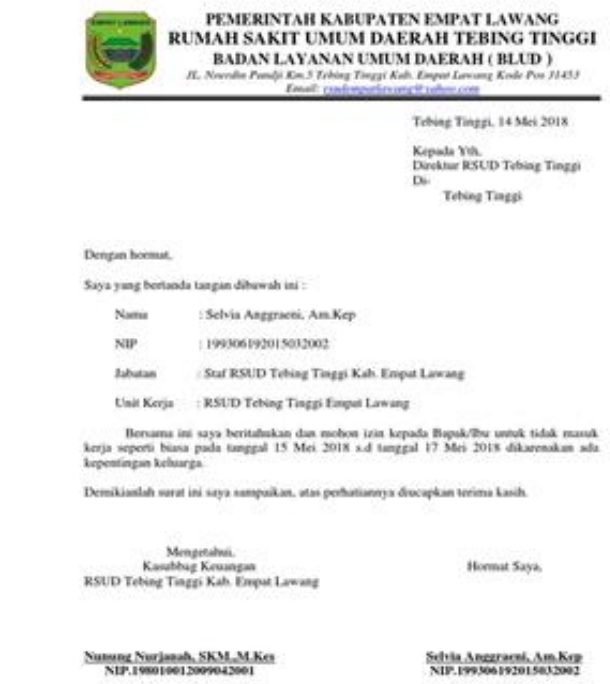

Gambar 16 Halaman Gambar Surat Keluar

\subsection{Pengujian Sistem}

Pengujian sistem adalah proses menganalisis kinerja sistem dengan menyesuaikan proses bisnis yang telah ada. Pengujian yang dilakukan penulis adalah dengan pengujian blackbox. tujuannya adalah untuk mengetahui kualitas dari sistem yang telah dibuat apakah sesuai dengan yang diharapkan atau belum. Tujuan pengujian blackbox yaitu untuk memastikan sistem dapat berjalan dengan baik, sehingga dapat meminimalisasikan human error.

\subsubsection{Pengujian Blackbox}

Pengujian dengan metode blackbox merupakan pengujian yang difokuskan kepada fungsionalitas sistem dalam mengelola data surat masuk dan surat keluar dan juga mengetahui kemampuan sistem dalam menangani kesalahan-kesalahan yang dilakukan oleh pengguna. Hasil dari pengujian blackbox dapat dilihat pada Tabel 2 sampai dengan Tabel 2

Tabel 2. SC-01 Proses Login (UCD-01)

\begin{tabular}{|c|c|c|c|}
\hline No & \multicolumn{1}{|c|}{ Skenario } & Hasil yang diharapkan & Kesimpulan \\
\hline $\begin{array}{l}\text { User mengetik } \\
\text { localhost/pengelolaansurat }\end{array}$ & Menampilkan halaman login & Berhasil \\
\hline
\end{tabular}




\begin{tabular}{|c|c|c|}
\hline $\begin{array}{l}\text { Memasukkan username dan } \\
\text { password dengan kondisi } \\
\text { (benar) lalu menekan } \\
\text { tombol Login }\end{array}$ & $\begin{array}{l}\text { Berhasil masuk ke halaman } \\
\text { home }\end{array}$ & Berhasil \\
\hline $\begin{array}{l}\text { lika memasukkan username } \\
\text { dengan kondisi (salah) lalu } \\
\text { menekan tombol login }\end{array}$ & $\begin{array}{l}\text { Menampilkan pesan username } \\
\text { dan password salah dan } \\
\text { kembali ke halaman login }\end{array}$ & Berhasil \\
\hline $\begin{array}{l}\text { ¿lika memasukkan password } \\
\text { dengan kondisi (salah) lalu } \\
\text { menekan tombol login" }\end{array}$ & $\begin{array}{l}\text { Menampilkan pesan username } \\
\text { dan password salah dan } \\
\text { kembali } \\
\text { kehalaman login }\end{array}$ & Berhasil \\
\hline
\end{tabular}

Tabel 3 SC-02 Manajemen Surat Masuk (UCD-02)

\begin{tabular}{|c|c|c|c|}
\hline No. & Skenario & Hasil yang diharapkan & Kesimpulan \\
\hline 1. & Memilih menu surat masuk & $\begin{array}{l}\text { Menampilkan halaman surat } \\
\text { masuk }\end{array}$ & Berhasil \\
\hline 2. & $\begin{array}{l}\text { Menekan tombol tambah } \\
\text { data surat masuk }\end{array}$ & $\begin{array}{l}\text { Menampilkan halaman tambah } \\
\text { data surat masuk }\end{array}$ & Berhasil \\
\hline 3. & $\begin{array}{l}\text { Menambahkan data surat } \\
\text { masuk dengan kondisi } \\
\text { (benar) dan menekan } \\
\text { tombol simpan }\end{array}$ & $\begin{array}{l}\text { Data surat masuk berhasil } \\
\text { disimpan dan kembali ke } \\
\text { halaman surat Masuk }\end{array}$ & Berhasil \\
\hline 4. & $\begin{array}{l}\text { lika mengosongkan data } \\
\text { dan menekan tombol } \\
\text { simpan }\end{array}$ & $\begin{array}{l}\text { Menampilkan pesan peringatan } \\
\text { bahwa data harus di isi dan } \\
\text { tidak boleh dikosongka }\end{array}$ & Berhasil \\
\hline 5. & $\begin{array}{l}\text { lika memasukkan nomor } \\
\text { surat yang sama lalu } \\
\text { menekan tombol simpan }\end{array}$ & $\begin{array}{l}\text { Menampilkan pesan peringatan } \\
\text { bahwa nomor surat sudah } \\
\text { digunakan dan kembali ke } \\
\text { halamantambah data surat } \\
\text { masuk }\end{array}$ & Berhasil \\
\hline 6. & $\begin{array}{l}\text { Menekan tombol lihat } \\
\text { (preview) file gambar surat } \\
\text { masuk }\end{array}$ & Menampilkan file surat masuk & Berhasil \\
\hline 7. & $\begin{array}{l}\text { Menekan tombol ubah } \\
\text { surat masuk }\end{array}$ & $\begin{array}{l}\text { Menampilkan halaman pop-up } \\
\text { dan menampilkan data surat } \\
\text { masuk Sebelumnya }\end{array}$ & Berhasil \\
\hline
\end{tabular}




\begin{tabular}{|l|l|l|l|}
\hline 8. & $\begin{array}{l}\text { Mengubah data surat } \\
\text { masuk kemudian menekan } \\
\text { tombol simpan }\end{array}$ & $\begin{array}{l}\text { Data berhasil diubah dan } \\
\text { kembali ke halaman surat } \\
\text { masuk }\end{array}$ & Berhasil \\
\hline 9. & $\begin{array}{l}\text { ika mengosongkan data } \\
\text { edit surat masuk dan } \\
\text { menekan tombol simpan }\end{array}$ & $\begin{array}{l}\text { Menampilkan pesan peringatan } \\
\text { bahwa data harus di isi dan } \\
\text { tidak boleh dikosongkan }\end{array}$ & Berhasil \\
\hline 10. & $\begin{array}{l}\text { Menekan tombol hapus } \\
\text { surat masuk }\end{array}$ & $\begin{array}{l}\text { Menampilkan pesan peringatan } \\
\text { untuk menghapus data surat } \\
\text { masuk yang dipilih }\end{array}$ & Berhasil \\
\hline 11. & $\begin{array}{l}\text { Menekan tombol down/oad } \\
\text { laporan surat masuk }\end{array}$ & $\begin{array}{l}\text { Menampilkan halaman pop-up } \\
\text { download laporan surat masuk }\end{array}$ & Berhasil \\
\hline 12. & $\begin{array}{l}\text { ika mengosongkan tanggal } \\
\text { laporan surat masuk dan } \\
\text { menekan tombol download }\end{array}$ & $\begin{array}{l}\text { Menampilkan pesan peringatan } \\
\text { bahwa tanggal laporan surat } \\
\text { masuk harus di isi dan tidak } \\
\text { boleh dikosongkan }\end{array}$ & Berhasil \\
\hline 13. & $\begin{array}{l}\text { Mengisi tanggal dari dan } \\
\text { tanggal sampai lalu } \\
\text { menekan tombol down/oad }\end{array}$ & $\begin{array}{l}\text { Meng-unduh laporan surat } \\
\text { masuk dalam bentuk excel }\end{array}$ & Berhasil \\
\hline
\end{tabular}

Tabel 4 SC-03 Manajemen Surat Keluar (UCD-03)

\begin{tabular}{|l|l|l|l|}
\hline No. & \multicolumn{1}{|c|}{ Skenario } & \multicolumn{1}{|c|}{ Hasil yang diharapkan } & Kesimpulan \\
\hline 1. & Memilih menu surat keluar & $\begin{array}{l}\text { Menampilkan halaman surat } \\
\text { keluar }\end{array}$ & Berhasil \\
\hline 2. & Menekan tombol tambah & $\begin{array}{l}\text { Menampilkan halaman pop-up } \\
\text { data surat keluar }\end{array}$ & Berhasil \\
\hline 3. & $\begin{array}{l}\text { Menambahkan data surat } \\
\text { keluar dengan kondisi } \\
\text { (benar) dan menekan } \\
\text { tombol tambah }\end{array}$ & $\begin{array}{l}\text { Data surat keluar berhasil } \\
\text { disimpan dan kembali ke } \\
\text { halaman surat keluar }\end{array}$ & Berhasil \\
\hline 4. & $\begin{array}{l}\text { Menekan tombol detail } \\
\text { surat keluar }\end{array}$ & $\begin{array}{l}\text { Menampilkan halama pop-up } \\
\text { detail surat keluar }\end{array}$ & Berhasil \\
\hline 5. & $\begin{array}{l}\text { Menekan tombol ubah } \\
\text { surat keluar }\end{array}$ & $\begin{array}{l}\text { Menampilkan halaman pop-up } \\
\text { ubah surat keluar dan } \\
\text { menampilkan data surat keluar } \\
\text { sebelumnya }\end{array}$ & Berhasil \\
\hline 6. & $\begin{array}{l}\text { Mengubah data surat } \\
\text { keluar kemudian menekan } \\
\text { tombol Simpan }\end{array}$ & $\begin{array}{l}\text { Data berhasil diubah dan } \\
\text { kembali ke halaman surat } \\
\text { keluar }\end{array}$ & Berhasil \\
\hline
\end{tabular}




\begin{tabular}{|c|c|c|c|}
\hline 7. & $\begin{array}{l}\text { lika mengosongkan data } \\
\text { edit surat keluar dan } \\
\text { menekan tombol simpan }\end{array}$ & $\begin{array}{l}\text { Menampilkan pesan peringatan } \\
\text { bahwa data harus di isi dan } \\
\text { tidak boleh dikosongkan }\end{array}$ & Berhasil \\
\hline 8. & $\begin{array}{l}\text { Menekan tombol hapus } \\
\text { surat keluar }\end{array}$ & $\begin{array}{l}\text { Menampilkan halaman pop-up } \\
\text { peringatan untuk menghapus } \\
\text { data surat keluar yang dipilih }\end{array}$ & Berhasil \\
\hline 9. & $\begin{array}{l}\text { Menekan tombol lihat } \\
\text { (preview) file gambar surat } \\
\text { Keluar }\end{array}$ & Menampilkan file surat keluar. & Berhasil \\
\hline 10. & $\begin{array}{l}\text { Menekan tombol download } \\
\text { laporan surat keluar }\end{array}$ & $\begin{array}{l}\text { Menampilkan halaman pop-up } \\
\text { download laporan surat keluar }\end{array}$ & Berhasil \\
\hline 11. & $\begin{array}{l}\text { ika mengosongkan tanggal } \\
\text { laporan surat keluar dan } \\
\text { menekan tombol download }\end{array}$ & $\begin{array}{l}\text { Menampilkan pesan peringatan } \\
\text { bahwa tanggal laporan surat } \\
\text { keluar harus di isi dan tidak } \\
\text { boleh dikosongkan" }\end{array}$ & Berhasil \\
\hline 12. & $\begin{array}{l}\text { Mengisi tanggal dari dan } \\
\text { tanggal sampai lalu } \\
\text { menekan tombol download }\end{array}$ & $\begin{array}{l}\text { Meng-unduh laporan surat } \\
\text { keluar dalam bentuk excel }\end{array}$ & Berhasil \\
\hline
\end{tabular}

Tabel 5 SC-04 Manajemen Disposisi Surat (UCD-04)

\begin{tabular}{|l|l|l|l|}
\hline No. & \multicolumn{1}{|c|}{ Skenario } & \multicolumn{1}{|c|}{ Hasil yang diharapkan } & Kesimpulan \\
\hline 1. & $\begin{array}{l}\text { Menekan tombol cetak } \\
\text { lembar surat disposisi pada } \\
\text { menu surat Masuk }\end{array}$ & $\begin{array}{l}\text { Menampilkan lembar disposisi } \\
\text { surat yang siap untuk dicetak }\end{array}$ & Berhasil \\
\hline 2. & $\begin{array}{l}\text { Menekan tombol disposisi } \\
\text { surat }\end{array}$ & $\begin{array}{l}\text { Menampilkan halaman disposisi } \\
\text { surat }\end{array}$ & Berhasil \\
\hline 3. & $\begin{array}{l}\text { Menekan tombol tambah } \\
\text { data disposisi surat }\end{array}$ & $\begin{array}{l}\text { Menampilkan halaman tambah } \\
\text { data disposisi surat }\end{array}$ & Berhasil \\
\hline 4. & $\begin{array}{l}\text { Menambahkan data } \\
\text { disposisi surat dengan } \\
\text { kondisi (benar) dan } \\
\text { menekan tombol simpan }\end{array}$ & $\begin{array}{l}\text { Data disposisi surat berhasil } \\
\text { disimpan dan kembali ke } \\
\text { halaman disposisi surat }\end{array}$ & Berhasil \\
\hline 5. & $\begin{array}{l}\text { Menekan tombol ubah data } \\
\text { disposisi surat }\end{array}$ & $\begin{array}{l}\text { Menampilkan halaman pop-up } \\
\text { dan menampilkan data disposisi } \\
\text { surat sebelumnya }\end{array}$ & Berhasil \\
\hline 6. & $\begin{array}{l}\text { Mengubah data disposisi } \\
\text { surat kemudian menekan } \\
\text { tombol simpan }\end{array}$ & $\begin{array}{l}\text { Data berhasil diubah dan } \\
\text { kembali ke halaman disposisi } \\
\text { surat }\end{array}$ & Berhasil \\
\hline
\end{tabular}


Journal of Information Technology Ampera

Vol. 2, No. 3, December 2021 e-ISSN: 2774-2121

https://journal-computing.org/index.php/journal-ita/index

\begin{tabular}{|l|l|l|l|}
\hline 7. & $\begin{array}{l}\text { Menekan tombol hapus } \\
\text { disposisi surat }\end{array}$ & $\begin{array}{l}\text { Menampilkan halaman pop-up } \\
\text { peringatan untuk menghapus } \\
\text { data surat keluar yang dipilih }\end{array}$ & Berhasil \\
\hline
\end{tabular}

Berdasarkan sembilan skenario yang dibuat penulis dengan tingkat keberhasilan pengujian masing-masing skenario adalah $100 \%$ maka hasil dari pengujian blackbox dapat disimpulkan bahwa sistem dapat berjalan baik dengan persentase keberhasilan $100 \%[6]$.

\section{KESIMPULAN}

Berdasarkan dari hasil kajian, landasan teori, analisa perancangan, hasil pembahasan dan pengujian sistem yang telah dilakukan maka diperoleh kesimpulan bahwa Sistem Informasi Layanan Surat Masuk dan Surat Keluar pada Pemerintahan Kabupaten Empat Lawng telah selesai dilakukan. Terdapat tujuh fitur pada Sistem Informasi Layanan Surat Masuk dan Surat Keluar yaitu Manajemen Surat Masuk, Manajemen Disposisi Surat, Manajemen Surat Keluar, Manajemen Kode Surat, Manajemen Agenda Acara, Manajemen Data Pegawai dan Manajemen Hak Akses. Berdasarkan Tujuh skenario dengan persentase keberhasilan $100 \%$ yang dibuat oleh penulis pada pengujian blackcbox bahwa Sistem Informasi Layanan Surat Masuk dan Surat Keluar Keluar sesuai dengan prosedur proses layanan surat masuk dan surat keluar pada Pemerintahan Kabupaten Empat Lawang.

\section{DAFTAR PUSTAKA}

[1] Nirsal Analisis Dan Perancangan Sistem Informasi Pengelolaan Surat Pada Universitas Cokroaminoto Palopo 2019.

[2] Balubita, H.; Si, S.; Kom, M.; Permatasari, M. Aplikasi Pencatatan Surat Masuk Dan Surat Keluar Di BP3TKI Bandung. 6.

[3] Chandra, J.; Putri, H. APLIKASI PENGELOLAAN SURAT MASUK, SURAT KELUAR SERTA PEMBUATAN SURAT PERINTAH PERJALANAN (Studi Kasus: Dinas (SPPD) Di KPU Prov. Jawa Barat). 2019.

[4] Samopa, F.; Hakim, J.A.R. Pembuatan Sistem Informasi Penatausahaan Surat dan Arsip Berbasis Web Studi Kasus Kantor Pelayanan Perbendaharaan Negara Bengkulu. 2013, 2, 4.

[5] Rosyanto, A.; Oleh, D. Pembuatan Aplikasi Surat Menyurat Elektronik Berbasis Web Di Pemerintahan Kota Yogyakarta Skripsi. $2010,362$.

[6] Rafidah, I. Sistem Informasi Pengelolaan Surat Masuk Dan Surat Keluar Di Kecamatan Ngemplak Yogyakarta. 98. 